International Journal of Agriculture, Environment and Bioresearch

Vol. 4, No. 05; 2019

ISSN: $2456-8643$

\title{
CONSUMERS' PREFERENCE IN DINING AT MALAYSIAN BRAND FAST FOOD RESTAURANTS
}

\author{
Siti Aishah Md Ismail ${ }^{1}$, Zainalabidin Mohamed ${ }^{1}$ and Haidy Khaizy ${ }^{1}$ \\ ${ }^{1}$ Department of Agribusiness and Bioresource Economics, Faculty of Agriculture, Universiti Putra Malaysia, 43400 \\ UPM Serdang, Malaysia \\ http://doi.org/10.35410/IJAEB.2019.4433
}

\begin{abstract}
Due to hectic schedules in urban areas and income increases, consumers prefer to have their food instantly. Rapid development of socio-economic status has create changes of consumer's habit especially for the food they consumed. This has led to the emergence and growth of international fast food restaurants such as KFC and McDonalds. This also had appointed the establishment of local brands fast food restaurants such as The Chicken Rice Shop, Papparich and Marrybrown. Trending eating in Malaysia happened when the number of careers women's has been rose up which led them do not have enough time in preparing food, consumers are becoming sophisticated to have bonding time with their loved one at fast food restaurants which contribute in arising consumers' food service sales. The main objective of this study was to determine the association between socio-demographic of consumers preference and main reason for going to eat at Malaysian brand fast food restaurant. The Chi-square results revealed consumers demographic profiles such as education level, occupation, income level, gender, marital status and lifestyle were significantly associated with consumers' preference and the main reason for going to dine at Malaysian brand fast food restaurants with the reasons of saving their time for cooking as well as to socialize with friends.
\end{abstract}

Keywords: Consumers' preference, fast food restaurants, chi-square analysis.

\section{INTRODUCTION}

Rapid development in lifestyle and a good economic structure had occurred among people in the world including education, employability, income, ICT and lifestyles. This phenomenon has brought many changes in consumer preferences in the country to have a modern lifestyle which include the habits of food consumption. Changing of socio demographic and lifestyle of consumer due to urbanization and influence of western culture, it brought a tremendous shifter pattern towards food consumption among Malaysian consumers. It has been identified by the statistic which shows a great rising of household income among Malaysian and the increasing of customer's purchasing power to buy what they needs and wants.

According to Department of Statistics Malaysia [1] on the household income and expenditure survey (HIES), the average household monthly income among Malaysian citizen had increased from RM6,141 to RM6,958 in 2014 and 2016 respectively. While the average household 
consumption expenditure for Malaysia had increased from RM3,578 in 2014 to RM4,033 in 2016. The data also reported that the average household consumption in urban areas had increased by about 5.8 percent yearly from RM3,921 to RM4,402, meanwhile rural increased at 5.7 percent annually from RM2,431 to RM2,725 in 2014 to 2016 . Moreover, the data showed the main household consumption expenditure in Malaysia are including food and non-alcoholic beverages which accounted about 18.0 percent as well as restaurants and hotels contributed about 13.4 percent higher among others composition listed.

Due to urbanization and changing of busy lifestyle toward modern and Westernize, people would like to have meal away from their home. Malaysians households spent about 30.8 percent of their disposal income on food and food away from home in 2016 compared 10.5 percent in 2004 [2]. This also supported by the study conducted from [3] which revealed that American households' expenditure towards foodservice will continue to increase when their income is higher. This is due to lack of time to cook at home, increasing of women working outside from house aside consumer more prefer to have their meal at fast food restaurants. According to [4], fast food can be described as a frequent selection among consumers, easy to get, tasty and affordable. Fast food restaurants usually have a walk up counters and/or drive-thru window where consumers just to say their order and pick up their food without having to wait so long. [5] stated that fast food is a food prepared in a restaurant with limited service staff and from which the majority of meals are consumed off premises. Fast food industry has become globally worldwide franchised business in all over country in the world with no barriers to entry. According to [6] fast food is one typical of global business. Fast food restaurant and services had continued to boost popularity even in Malaysia, especially in urban area and had become as Malaysian choice place for eating.

The first fast food restaurant in Malaysia is A\&W. Since then, customer acceptance toward fast food are increasing and the establishment of many fast food restaurants were introduced and expands such as McDonald's, Kentucky Fried Chicken, and Subway. Fast food is the fastest growing industry throughout the world, especially in urban areas as it provides many advantages to the community such as convenient, quick services, cheaper, and instantly available option to home food based [7]. In 2014, there are over thousands of international fast food restaurant operated in Malaysia. Majority of fast food restaurants outlet in Malaysia were dominated by American franchises such as Kentucky Fried Chicken (KFC) which is over than 600 outlets [8], Pizza hut reached about 350 outlets [9], McDonalds with 260 outlets [10], A\&W with the number of 49 outlets [11], Nando's with 78 outlets [12] and Subway with 50 number of outlets [13] respectively. They serve western food such as burger, pizza, nugget and fried chicken.

The rise of fast food restaurants generally franchise from other countries which lead in boost up local entrepreneurs to start manage local fast food restaurants. The first local fast food restaurant that has been established was Marrybrown in 1981. Marrybrown serves westernized food such as fried chicken, burger and beverages. Malaysian fast food known as kopitiam has now become popular among Malaysian. Popularity of Malaysian Delight outlet is attribute largely from introduction of Malaysian food and beverages such as Nasi Lemak, Mee Kari, laksa and Teh Tarik. All items are prepared with fresh finest ingredient to retain its original flavour. The 
decoration of the restaurants are essentials to fulfil relaxing ambience, clean environment and enjoyable moment while consumers enjoying their food. Table 1 shows the rising and famous Malaysian fast food restaurants among people in Malaysia.

Table 1: Malaysian Fast Food Franchise

\begin{tabular}{|ll|}
\hline Franchised & Year established \\
\hline Marrybrown & 1981 \\
Ayamas & 1988 \\
Old Town White Coffee & 1999 \\
Chicken Rice Shop & 2000 \\
Papparich & 2005 \\
Bangi Kopitiam & 2006 \\
Legend's Claypot Briyani & 1997 \\
SCR Xpress & 1987 \\
\hline
\end{tabular}

Source: Malaysian Franchise Association [14]

\section{MATERIALS AND METHODS}

\subsection{Survey Questionnaire}

A questionnaire survey based on the objectives of the study was conducted in this study of the households in Klang Valley area due to various types of backgrounds of the sample can be taken such as university students, employments with different levels of income, different types of races, highly numbers of population aside it is become one of the major developing living areas in Malaysia as well. The 300 respondents will be selected randomly by whom has leisure time around Klang Valley and the tendencies for being selected individually is high.

\subsection{Statistical Analysis}

To make it clearly defined about consumers' preference and the main reason for going to eat at Malaysian brand fast food restaurants, two methods of analysis assigned to be used which are descriptive analysis and chi-square analysis. The descriptive analysis to show the general outcome and reasons of the frequency distribution of the variables in this survey. The nominal variable can be described in terms of their frequency distribution and percentages while the central tendency of the variables can be described in terms of mean, median and mode. Chisquare analysis attempted to determine the significant association between the variables which is the difference between observed frequency distribution and the expected frequency distribution due to sampling variation. In this study, the level of significance of ten percent being selected to be used and the basic idea of $\chi^{2}$ is to compare the observation with the expected frequency when the null hypothesis is true. The $\chi^{2}$ is computed using the formula such below:

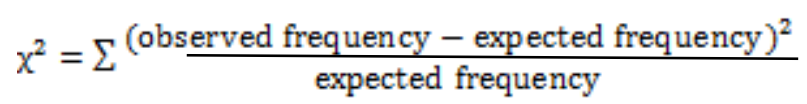

The suggested null hypothesis $\left({ }^{H_{0} H_{0}}\right)$ based on the selected socio-demographic profiles with consumer preference for going to eat at Malaysian brand fast food restaurants and between socio- 
demographic profiles with the main reason for going to Malaysian brand fast food restaurants can be concluded such below:

$H_{0}: H_{0}:$ There is no significant association between socio-demographic profiles with consumers' preference to eat at Malaysian brand fast food restaurants

$H_{0}: H_{0}:$ There is no significant association between socio-demographic profiles with the main reason for going to Malaysian brand fast food restaurants.

$\boldsymbol{H}_{1} \boldsymbol{H}_{1}$ : There is a significant association between socio-demographic profiles with consumers' preference to eat at Malaysian brand fast food restaurants,

$H_{1} H_{1}$ : There is a significant association between socio-demographic profiles with the main reason for going to Malaysian brand fast food restaurants.

\section{RESULTS AND DISCUSSION}

\subsection{Descriptive Analysis}

In this study, this method was conducted to analyse the respondents' socio demographic profiles towards Malaysian brand fast food restaurants. Demographic profiles of $n=300$ households are shown in Table 2. The large number of the respondents involved were younger which is between age of 21-30 ( $n=116$ respondents) followed by age between 31-40 ( $n=87$ respondents), and the lowest contributed by age which is above 51 years old. The majority of the households have their tertiary level of education ( $n=245$ respondents) as their educational background and work in private and government sectors. The biggest number of income level of the households contributed by the income level which is below RM1500 (33.3 percent) and the smallest contributed by the households income level above RM 6001 with the percentage of 10.3 percent. The respondents lifestyle contributed by career people who occupied about 41.3 percent and most of the respondents are staying at the urban area (81.0 percent) compared to rural areas (19.0 percent). The number of respondents who experienced eaten at Malaysian Brand Fast Food restaurant was about $n=276$ respondents (92.0 percent) while the rest $n=24$ respondents accounted about 8.0 percent never been eat there.

Table 2: Respondent's Socio-Demographic Profile and Experienced Eating at Malaysian Brand Fast Food Restaurants

\begin{tabular}{|llll|}
\hline Demographic Variable & Description & $\begin{array}{l}\text { Frequency } \\
(\boldsymbol{n = 3 0 0 )}\end{array}$ & $\begin{array}{l}\text { Percentage } \\
(\boldsymbol{\%})\end{array}$ \\
\hline \multirow{2}{*}{ Gender } & Male & 133 & 44.3 \\
& Female & 167 & 55.7 \\
\hline \multirow{3}{*}{ Age } & Below 20 & 36 & 12.0 \\
& $21-30$ & 116 & 38.7 \\
& $31-40$ & 87 & 29.0 \\
& $41-50$ & 50 & 16.7
\end{tabular}




\begin{tabular}{|c|c|c|c|}
\hline & Above 51 & 11 & 3.7 \\
\hline \multirow{2}{*}{ Marital Status } & Single & 142 & 47.3 \\
\hline & Married & 158 & 52.7 \\
\hline \multirow{2}{*}{ Area } & Urban & 243 & 81 \\
\hline & Rural & 57 & 19 \\
\hline \multirow{3}{*}{ Educational Level } & Primary education & 5 & 1.7 \\
\hline & Secondary education & 50 & 16.7 \\
\hline & Tertiary education & 245 & 81.7 \\
\hline \multirow{5}{*}{ Occupation } & Government & 95 & 31.7 \\
\hline & Private & 98 & 32.7 \\
\hline & Self-employed & 18 & 6.0 \\
\hline & Student & 84 & 28.0 \\
\hline & Others & 5 & 1.7 \\
\hline \multirow{4}{*}{ Lifestyle } & Career people & 124 & 41.3 \\
\hline & Sport & 37 & 12.3 \\
\hline & Outing & 55 & 18.3 \\
\hline & Socialize & 84 & 28.0 \\
\hline \multirow{5}{*}{ Income Level } & below RM 1500 & 100 & 33.3 \\
\hline & RM 1501 -RM 3000 & 63 & 21.0 \\
\hline & RM 3001 - RM 4500 & 57 & 19.0 \\
\hline & RM 4501 - RM 6000 & 49 & 16.3 \\
\hline & above RM 6001 & 31 & 10.3 \\
\hline \multirow{2}{*}{$\begin{array}{l}\text { Have been eaten at } \\
\text { Malaysian Brand Fast } \\
\text { food restaurants }\end{array}$} & Yes & 276 & 92.0 \\
\hline & No & 24 & 8.0 \\
\hline
\end{tabular}

\subsection{Chi-Square Analysis}

Chi-square analysis was selected to be used to identify the significant difference or association of two variables which is between socio-demographic profiles and consumers' preference and main reason for going to eat at Malaysian brand fast food restaurants.

Table 3: Summary of the Association between Socio-Demographic Profiles Variables with Preference to Eat at Malaysian Brand Fast Food Restaurants

\begin{tabular}{lllll}
\hline Variable & $\chi^{\mathbf{2}}$ & df & Significant & Reject $\mathbf{H}_{\mathbf{0}}$ \\
\hline Education level & 4.909 & 2 & 0.086 & Reject \\
Occupation & 8.981 & 4 & 0.062 & Reject \\
Income level & 8.063 & 4 & 0.089 & Reject \\
Area & 0.004 & 1 & 0.953 & Fail to Reject \\
Marital status & 1.383 & 1 & 0.240 & Fail to Reject \\
\hline
\end{tabular}

Note: ** statistically significant at 0.01 level 
International Journal of Agriculture, Environment and Bioresearch

Vol. 4, No. 05; 2019

ISSN: $2456-8643$

Table 4: Association between Socio-Demographic Profiles with Preference to Eat at Malaysian Brand Fast Food Restaurants

\begin{tabular}{|c|c|c|}
\hline Education level & $\begin{array}{l}\text { Preference to eat } \\
(\text { mean }<2.91)\end{array}$ & $\begin{array}{l}\text { Preference to eat } \\
(\text { mean }>2.91)\end{array}$ \\
\hline Primary education & 4.0 & 0.5 \\
\hline Secondary education & 15.8 & 17.1 \\
\hline Tertiary education & 80.2 & 82.4 \\
\hline Occupation & $\begin{array}{l}\text { Preference to eat } \\
(\text { mean }<2.91)\end{array}$ & $\begin{array}{l}\text { Preference to eat } \\
(\text { mean }>2.91)\end{array}$ \\
\hline Government sector & 31.7 & 31.7 \\
\hline Private sector & 33.7 & 32.2 \\
\hline Self-employed & 2.0 & 8.0 \\
\hline Student & 28.7 & 27.6 \\
\hline Others & 4.0 & 0.5 \\
\hline Income level & $\begin{array}{l}\text { Preference to eat } \\
(\text { mean }<2.91)\end{array}$ & $\begin{array}{l}\text { Preference to eat } \\
(\text { mean }>2.91)\end{array}$ \\
\hline Below RM1500 & 31.7 & 34.2 \\
\hline RM1501- RM3000 & 13.9 & 24.6 \\
\hline RM3001- RM4500 & 25.7 & 15.6 \\
\hline RM4501- RM6000 & 18.8 & 15.1 \\
\hline Above RM6001 & 9.9 & 10.6 \\
\hline Area & $\begin{array}{l}\text { Preference to eat } \\
(\text { mean }<2.91)\end{array}$ & $\begin{array}{l}\text { Preference to eat } \\
(\text { mean }>2.91)\end{array}$ \\
\hline Urban & 81.2 & 80.9 \\
\hline Rural & 18.8 & 19.1 \\
\hline Marital Status & $\begin{array}{l}\text { Preference to eat } \\
(\text { mean }<2.91)\end{array}$ & $\begin{array}{l}\text { Preference to eat } \\
(\text { mean }>2.91)\end{array}$ \\
\hline Married & 57.4 & 50.3 \\
\hline Single & 42.6 & 49.7 \\
\hline
\end{tabular}

Table 3 shows the summary of the chi-square between socio-demographic profiles with preference to eat at Malaysian Brand Fast Food Restaurants. The socio-demographic variables that were used for the purpose of chi-square analysis for dummy were age, gender, marital status, area, education level, occupation, lifestyle and income level. The results on Table 4 will be further explained in the summary results. It shows a significant association between educational levels with consumers' preference to eat at Malaysian fast food restaurants. Most of respondents have their study in tertiary education level which accounted for about 80 percent (245 respondents). According to [15], tertiary and higher level of education were more likely to agree that they eat fast food to save their time because they are too busy to cook.

Most of the respondents are working in private and government sector contributed about 30.0 percent with the number of 98 respondents and 95 respondents respectively. It shows that people who are working have higher tendencies to choose eating on quick meal solutions due to the busier lifestyle and dual-working families with children. Due to this also, the time available to 
cook meals is being squeezed between work and leisure commitments. The income level contributed about 33.0 percent of the respondents who earned monthly income below than RM1500. Income below RM1500 mainly constituted among students and housewives which prefer to buy a local fast food with affordable prices compared to high income which prefer to eat at Western fast food restaurants more [16]. The results identified that area and marital status do not have significant with the value of 81.0 percent of them living in urban areas while 19 percent of them were living in rural areas as well as marital status accounted about 47.8 percent of single respondents and 53.0 percent of married respondents.

Table 5: Summary of the Association between Socio-Demographic Profiles Variables with Main Reason for Going to Dine at Malaysian Brand Fast Food Restaurants

\begin{tabular}{|lllll|}
\hline Variable & $\boldsymbol{\chi}^{\mathbf{2}}$ & df & Significant & Reject $\mathbf{H}_{\mathbf{0}}$ \\
\hline Gender & 15.310 & 4 & $* * 0.004$ & Reject \\
Marital status & 13.682 & 4 & $* 0.008$ & Reject \\
Lifestyle & 19.845 & 12 & $* 0.070$ & Reject \\
Income level & 32.168 & 16 & $* * 0.010$ & Reject \\
Area & 5.281 & 4 & 0.260 & Fail to Reject \\
\hline
\end{tabular}

Note: $* *$ statistically significant at 0.01 level and $* 0.05$ level

Table 6: Association between Socio-Demographic Profiles with Main Reason for Going to Dine at Malaysian Brand Fast Food Restaurants

\begin{tabular}{|c|c|c|c|c|c|}
\hline Gender & $\begin{array}{l}\text { To get } \\
\text { their } \\
\text { food } \\
(\%)\end{array}$ & $\begin{array}{l}\text { To } \\
\text { socialize } \\
\text { with } \\
\text { friends } \\
(\%)\end{array}$ & $\begin{array}{l}\text { Take leisure } \\
\text { time } \\
(\%)\end{array}$ & $\begin{array}{l}\text { Serving } \\
\text { good quality } \\
\text { food }(\%)\end{array}$ & $\begin{array}{l}\text { Reducing time } \\
\text { preparing food } \\
\text { at home }(\%)\end{array}$ \\
\hline \multirow{2}{*}{$\begin{array}{l}\text { Male } \\
\text { Female }\end{array}$} & 43.0 & 53.8 & 53.7 & 46.2 & 19.0 \\
\hline & 57.0 & 46.2 & 46.3 & 53.8 & 81.0 \\
\hline \multirow[t]{2}{*}{ Marital status } & $\begin{array}{l}\text { To get } \\
\text { their } \\
\text { food } \\
(\%)\end{array}$ & $\begin{array}{l}\text { To } \\
\text { socialize } \\
\text { with } \\
\text { friends }(\%)\end{array}$ & $\begin{array}{l}\text { Take leisure } \\
\text { time }(\%)\end{array}$ & $\begin{array}{l}\text { Serving } \\
\text { good quality } \\
\text { food }(\%)\end{array}$ & $\begin{array}{l}\text { Reducing time } \\
\text { preparing food } \\
\text { at home }(\%)\end{array}$ \\
\hline & 47.0 & 66.2 & 38.9 & 41.0 & 35.7 \\
\hline $\begin{array}{l}\text { Single } \\
\text { Married }\end{array}$ & 53.0 & 33.8 & 61.1 & 59.0 & 64.3 \\
\hline Lifestyle & $\begin{array}{l}\text { To get } \\
\text { their } \\
\text { food } \\
(\%)\end{array}$ & $\begin{array}{l}\text { To } \\
\text { socialize } \\
\text { with } \\
\text { friends }(\%)\end{array}$ & $\begin{array}{l}\text { Take leisure } \\
\text { time }(\%)\end{array}$ & $\begin{array}{l}\text { Serving } \\
\text { good quality } \\
\text { food }(\%)\end{array}$ & $\begin{array}{l}\text { Reducing time } \\
\text { preparing food } \\
\text { at home }(\%)\end{array}$ \\
\hline Career people & 41.0 & 32.3 & 40.7 & 35.9 & 61.9 \\
\hline Sporty & 8.0 & 10.8 & 16.7 & 20.5 & 11.9 \\
\hline Outing & 22.0 & 18.5 & 20.4 & 20.5 & 4.8 \\
\hline Socialize & 29.0 & 38.5 & 22.2 & 23.1 & 21.4 \\
\hline
\end{tabular}


International Journal of Agriculture, Environment and Bioresearch

Vol. 4, No. 05; 2019

ISSN: $2456-8643$

\begin{tabular}{|c|c|c|c|c|c|}
\hline Income level & $\begin{array}{l}\text { To get } \\
\text { their } \\
\text { food } \\
(\%)\end{array}$ & $\begin{array}{l}\text { To } \\
\text { socialize } \\
\text { with } \\
\text { friends }(\%)\end{array}$ & $\begin{array}{l}\text { Take leisure } \\
\text { time }(\%)\end{array}$ & $\begin{array}{l}\text { Serving } \\
\text { good quality } \\
\text { food }(\%)\end{array}$ & $\begin{array}{l}\text { Reducing time } \\
\text { preparing food } \\
\text { at home }(\%)\end{array}$ \\
\hline below RM1500 & 38.0 & 40.0 & 29.6 & 35.9 & 14.3 \\
\hline RM1501-RM3000 & 21.0 & 21.5 & 22.2 & 23.1 & 16.7 \\
\hline RM3001- RM4500 & 22.0 & 12.3 & 14.8 & 12.8 & 33.3 \\
\hline RM4501-RM6000 & 11.0 & 7.7 & 22.2 & 25.6 & 26.2 \\
\hline above RM6001 & 8.0 & 18.5 & 11.1 & 2.6 & 9.5 \\
\hline Area & $\begin{array}{l}\text { To get } \\
\text { their } \\
\text { food } \\
(\%)\end{array}$ & $\begin{array}{l}\text { To } \\
\text { socialize } \\
\text { with } \\
\text { friends (\%) }\end{array}$ & $\begin{array}{l}\text { Take leisure } \\
\text { time }(\%)\end{array}$ & $\begin{array}{l}\text { Serving } \\
\text { good quality } \\
\text { food }(\%)\end{array}$ & $\begin{array}{l}\text { Reducing time } \\
\text { preparing food } \\
\text { at home }(\%)\end{array}$ \\
\hline Urban & 77.0 & 81.5 & 77.8 & 82.1 & 92.9 \\
\hline Rural & 23.0 & 18.5 & 22.2 & 17.9 & 7.1 \\
\hline
\end{tabular}

The results summary on Table 5 shows that gender, marital status, lifestyle and income level had significant association with main reason for consumers to go to eat at Malaysian brand fast food restaurants. Table 6 further explained on the summary of the results. The data revealed that most females had reason to reduce time for preparing meals at home with the percentage of 81.0 percent compared to male respondents. Increasing number of women desire in working away from home and their value of time increases, more food will be eaten away from home [17]. Consumers prefer to get their food instantly while they can reduce time to queue and cooked at home. It is significant at the 99.0 percent level of confidence and we reject the null hypothesis. The marital status had significant association with the main reason of respondents to go Malaysian brand fast food restaurants with the level of significant at 99.0 percent. To socialize with friends at the restaurants is the main reason which comprised about 66.2 percent of respondents who is single while 33.8 percent were married respondents.

The association between respondent's lifestyle and main reason for going to Malaysian brand fast food restaurants were shown. The reason to reduce time for preparing food at home were made up by 61.9 percent of career people compared to other lifestyle. This because career people have no enough time to cook. The income level which is below RM1500 group (40.0 percent) has higher tendencies going to local fast food restaurants with the reasons they want to socialize with their friends and they prefer to choose cheaper one. Whilst the respondents with income above RM 6001 have only 18.5 percent for the same reason in the results. This is due to highincome respondents were more familiar with fast food as it is defined in the West, and they prefer to eat at western fast food restaurants more frequently rather than local fast food restaurants [18]. Respondents with different income level have different reason for going to Malaysian brand fast food restaurant based on what they needs and wants. The results stated that area do not have significant association with the main reason for going to Malaysia brand fast food restaurants as well as both urban and rural areas have their own choices rather than to eat at home or outside. 


\section{CONCLUSION AND RECOMMENDATIONS}

This is important to understand why Malaysian people prefer to eat outside and the reason why they choose eating outside rather than cooked and eat at home. Therefore, it is found that sociodemographic variables such as education level, occupation, income level, gender, marital status and lifestyle have a strong association with the consumers' preference and main reason of choosing to eat at Malaysian brand fast food restaurants due to saving time in preparing food at home as well as they choose to have bonding time with their friends at fast food restaurants. The result reveals that consumers' who has higher education level, occupation and income level have more preference to eat at Malaysian brand fast food whilst the income level, gender, marital status and lifestyle significantly influence consumers choose to eat at Malaysian brand fast food restaurants. This study help marketers to produce and create more product based on consumers need and wants. Moreover, the information from the study could help to develop better strategies on how to attract more local people to choose local fast food services. From the government side, the establishment of fast food restaurants will help promoting Malaysian food cultures, especially among younger people instead of encouraging more local people to establish local fast food restaurants.

\section{REFERENCES}

[1] Department of Statistic Malaysia. (2019). Household Income and Expenditure Survey (HIES) 2019. Available On-line at https://www.dosm.gov.my/v1/index.php?r=columncone\&menu_id=a2VmTzBMTnlpMmhWSEJ zYjJDSWROdz09

[2] Khazanah Research Research Institute (2018). The State of Households: Different Realities. Available On-line at http://www.krinstitute.org/assets/contentMS/img/template/editor/FullReport_KRI_SOH_2018.pd $\underline{\mathrm{f}}$

[3] Stewart, H., Blisard, N., Bhuyan, S., \& Nayga Jr, R. M. (2004). The demand for food away from home. US Department of Agriculture-Economic Research Service Agricultural Economic Report, 829.

[4] Xiao, A., Yang, S., \& Iqbal, Q. (2019). Factors affecting purchase intentions in generation Y: An empirical evidence from fast food industry in Malaysia. Administrative Sciences, 9(1).

[5] [16] [18] Aloia, C. R., Gasevic, D., Yusuf, S., Teo, K., Chockalingam, A., Patro, B. K.,... \& Lear, S. A. (2013). Differences in perceptions and fast food eating behaviours between Indians living in high-and low-income neighbourhoods of Chandigarh, India. Nutrition journal, 12(1), 1. [6] Emerson, R. L. (1990). The New Economics Of Fast Food. Van Nostrand Reinhold, New York

[7] Goyal, A., \& Singh, N. P. (2007). Consumer perception about fast food in India: an exploratory study. British Food Journal, 109(2), 182-195

[8] Kentucky Fried Chicken (KFC) Official Website. KFC Malaysia. Available On-line at https://dinein.kfc.com.my/kfc-malaysia. [Accessed: August. 10, 2019].

[9]Pizza Hut Official Website. Pizza hut Malaysia. Available On-line at https://www.pizzahut.com.my/aboutus [Accessed: August. 10, 2019]. 
[10] McDonald's Official Website. About McDonald's. Available On-line at https://www.mcdonalds.com.my/company [Accessed: August. 10, 2019].

[11] A\&W Official Website. A\&W Malaysia History. Available On-line at https://www.anwmalaysia.com.my/anw-malaysia-history [Accessed: August. 10, 2019].

[12] Nando's Official Website. Restaurant-Nandos' Malaysia. Available On-line at https://nandos.com.my/restaurants/ [Accessed: August. 10, 2019].

[13] Subway Official Website. Location. Available On-line at https://www.subway.com/enMY/FindAStore?zip=Malaysia [Accessed: August. 10, 2019].

[14] MFA. (2016). Malaysian Franchise Association. Available On-line at http://www.mfa.org.my/newmfa/business-directory/wpbdp_category/food-and-beverages/

[15] Rydell, S. A., Harnack, L. J., Oakes, J. M., Story, M., Jeffery, R. W., \& French, S. A. (2008). Why eat at fast-food restaurants: reported reasons among frequent consumers. Journal of the American Dietetic Association, 108(12), 2066-2070.

[17] McCracken, V. A., \& Brandt, J. A. (1987). Household consumption of food-away-fromhome: total expenditure and by type of food facility. American Journal of Agricultural Economics, 69(2), 274-284. 